\title{
Brittle Failure of Graphite Weakened by V-Notches: A Review of Some Recent Results under Different Loading Modes
}

\author{
F. Berto, ${ }^{1}$ A. Campagnolo, and P. Gallo \\ Department of Management and Engineering, University of Padua, Vicenza, Italy \\ ${ }^{1}$ berto@gest.unipd.it
}

УДК 539.4

\section{Хрупкое разрушение графитовых образцов с V-образным надрезом: обзор результатов новейших исследований при различных модах нагружения}

\author{
Ф. Берто, А. Кампаньоло, П. Галло
}

Факультет менеджмента и инжиниринга, Университет г. Падуя, Виченца, Италия

\begin{abstract}
Представлен обзор экспериментальных и расчетных результатов, полученных точными решениями и численными методами, новейших исследований хрупкого разрушения изостатического поликристаллического графита. Исследования проводили на образиах с V-образным надрезом при нагружении по смешанной моде (I+II) кручением и сжатием для различных комбинаций таких параметров, как радиус скругления, угол раствора и наклона V-образного надреза. Статическую прочность исследуемьх образцов оценивали в рамках подхода, базирующегося на осредненной по контрольному объему плотности энергии деформации. Центр контрольного объема находится в вершине надреза, где достигается максимальное значение главного напряжения. Точная ориентация контрольного объема оценивается путем жесткого вращения крестообразного участка, тогда как его размеры зависят от вязкости разрушения и предела прочности материала. Данная методология достаточно успешно была использована в литературных источниках для анализа $U$ - $и$ V-образных надрезов при нагружении по моде I, при этом получены хорошие результаты и некоторые преимущества по сравнению с классическими подходами. Показана хорошая сходимость экспериментальных $и$ расчетных результатов для случая нагружения по смешанной моде.
\end{abstract}

Ключевые слова: нагружение по смешанной моде, хрупкое разрушение, упругость, тупые надрезы, плотность энергии деформации.

Introduction. Fine grain cool press graphite is a widespread type material which was presented in the latest fifty years. It is produced by cold isostatic pressing (CIP) technology. It has many good excellent isotropic properties, such as good electric conductivity, heat conductivity, high strength under high temperature, self-lubrication and so on. In order to obtain an higher purification, it is possible to threat it in a special-designed graphitization furnace to remove non-carbonaceous inclusions and impurities. Moreover this kind of graphite presents high mechanical performances together with excellent oxidation resistance and for this reason is used in different engineering fields and industrial applications such as crucibles and molds for processing solar silicon, electrodes for plasma etching, slicing beams for cutting poly- and monocrystalline products, molds in continuous casting systems for making shaped steel, cast iron and copper, heating elements, heat shields, etc.

Because of its wide spread in very different industrial applications, there are several operating conditions in which notched graphite components are subjected to mixed mode I+II loading with a combination of tensile and shear deformation. Moulds, heating elements

(C) F. BERTO, A. CAMPAGNOLO, P. GALlO, 2015 
and chucks are only some examples of industrial graphite components that contain U- or V-shape notches. In such components, cracks are generated by the manufacturing process and, also paying high attention in the manufacturing stage, unavoidable defects are due to the coalescence of the micro-structural pores that are inherently embedded in graphite.

When dealing with brittle fracture, the fracture toughness is the conventional parameter used by engineers to assess the structural integrity of cracked specimens. Since the strategic importance of this variable, several researchers have tried to determine the fracture toughness of polycrystalline graphite under mode I or under mixed mode I+II loading conditions [1-26]. Especially Awaji and Sato [1], Li et al. [4], Yamauchi et al. [2, 3], and Shi et al. [5] conducted a large number of tests to determine fracture toughness under mode I and mixed mode I+II with different cracked specimens. Recently, the crack nucleation in poly-granular graphite has been investigated by Mostafavi and Marrow [22, 23]. They considered uniaxial and biaxial loading conditions, and suggested a model (that regarded a fictitious crack) to predict the behavior of crack nucleation in graphite components. Wang and Liu [6] also proposed an innovative technique, called the spiral notch torsion fracture toughness test. Thanks to their methodology, they were able to measure the mode I fracture resistance of graphite. Etter et al. [7], through single-edge notched beam specimens, measured mode I fracture toughness $K_{\mathrm{I} c}$ of isotropic polycrystalline porous graphite.

The wide spread of this material in the composites field such as graphite/epoxy composites, has also pushed some researchers to study the fracture resistance of graphite under pure mode I and mixed mode I+II loading conditions $[2,4]$. Other important aspects such as crack growth, the stress intensity factors, and also fracture toughness have been investigated by Latella and Liu [11] through the arc-discharge method. Jae et al. [10] instead preferred the laser irradiation technique.

Regarding thermal properties, thermal shock fracture toughness was investigated by Sato et al. [12]. They considered two different types of carbon as a function of heat treatment temperature during the graphitization process. Graphite components indeed sometimes work at high temperature environment. Moreover, Sato et al. [13] have evaluated the high temperature fracture toughness of graphite that can be used in such applications.

Another reading key for brittle fracture in graphite is a theoretical approach based on microstructural aspects. Several researchers have pushed their efforts in this direction (e.g., [14-21]). Among them, a well-known theory was proposed by Burchell [16]. It relates brittle fracture of graphite to the crack nucleation and the subcritical crack growth from pre-existing pores under the influence of the stress field related to the pores or defects. Lomakin et al. [17] instead, through an energy release rate criterion, analyzed the fracture initiation in cracked graphite specimens under mode I loading. Recently, some works on three-dimensional crack propagation in poly-granular graphite have been published [25].

The brief literature review on brittle failure of graphite documents that extensive studies on mode I and mixed mode fracture in cracked graphite specimens are available in literature [1-26], while a very limited number of works deals with brittle fracture (and notch sensitivity) of V-shaped and U-shaped notches [27, 28], despite the great interest on the topic. Worth mentioning are some pioneering papers $[29,30]$ and some quite recent contributions $[25,27]$. In order to investigate the notch sensitivity of isostatic graphite, remarkable experimental programme has been conducted by Berto et al. [31-34] considering different failure modes.

One of the most important theories in the context of brittle fracture of engineering components is certainly the strain energy density (SED) criterion. For cracked members, Sih [35] proposed the strain energy density factor (SEDF) by taking into account simultaneously both the strain energy density and the critical distance measured from the crack tip. According to the Sih criterion, brittle fracture takes place in a cracked brittle 
member when the SEDF attains its critical value [35]. The crack growth direction could also be determined by setting a minimum condition on the SEDF [35]. Furthermore, this theory was used to study three problems of structural failure, namely the problem of slow stable growth of an inclined crack in a plate subjected to uniaxial tension, the problem of fracture instability of a plate with a central crack and two notches, and the problem of unstable crack growth in a circular disc subjected to two equal and opposite forces. The results of stress analysis were combined with the strain energy density theory to obtain the whole history of crack growth from initiation to instability. A length parameter was introduced to define the fracture instability of a mechanical system. Fracture trajectories were obtained for fast unstable crack propagation. The study of crack initiation and propagation is still an active research topic as demonstrated by some recent papers in the field [36-40]. This is particularly true when complex loading modes are taken into account [41-43].

Dealing with failure assessment for brittle fracture in V-shaped and U-shaped notched components, a criterion based on the strain energy density (SED) over a control volume has been developed [44, 45] and applied successfully in the last years. Over a finite volume (also if very small) close to the notch, the energy can be always quantified in a finite value. For further details on the SED approach, the reader can refer to a recent review [46]. This parameter has been successfully used by Lazzarin et al. to assess the fracture strength of different materials, characterized by different control volumes and subjected to wide combinations of static loading [47-49]. Moreover, it has been successfully employed for the fatigue strength of welded joints [50,51] and notched components [52-55]. As shown by Lazzarin et al. [56], the SED can be easily evaluated numerically through finite element analysis by using coarse meshes, and it permits automatically to take into account higher order terms and three-dimensional effects $[57,58]$. These considerations are, among the others, the main advantages of the SED approach.

The control volume, over which the energy is averaged, is defined by a control radius $R_{0}$ that depends on the fracture toughness and the ultimate tensile strength of the material under hypothesis of static loading and brittle behavior. Unlike the criterion proposed by Sih [35], that is a point-based method, the averaged strain energy density criterion (SED) states that brittle failure occurs when the mean value of the strain energy density over a control volume (or an area in two dimensional cases) is equal to a critical energy $W_{c}$.

Recently, the SED criterion has been applied to mixed mode loading (see [59, 60]). Once the maximum value of the principal stress is known (along the notch edge), an accurate expression is proposed to evaluate the SED for U-notched specimens. The solution is based on the equivalent local mode I concept [60].

In the present paper, a study on brittle fracture of V-notched specimens made of isostatic graphite subjected to different loading modes is presented. The considered loading conditions are: mixed mode I+II, torsion and compression. The final aim is to provide a fracture model for the estimation of the critical loads to failure in notched components made of isostatic graphite. The strain energy density averaged on a control volume is proposed for brittle failure assessments of notched graphite specimens.

The main points addressed in this paper are: the first paragraph regards the experimental procedure and specimen geometries; the second section summarizes the results from a recent application of the SED criterion on U-notched graphite plates under mixed mode I+II loading; the third paragraph considers the application of the SED criterion to several experimental test obtained recently for U- and V-notched graphite cylindrical specimens subjected to torsion loading; in the fourth section it is described the application of the SED criterion to recent results from V-notches with end-holes, subjected to compression loading; at least, in the fifth paragraph, a synthesis of all data in terms of averaged SED over a control volume is presented. Once the results are completely reported, they are also deeply commented. 
1. Experimental Tests. In order to better investigate the notch sensitivity of isostatic graphite, considering different failure modes, a large experimental programme has been conducted by Berto et al. [31-34]. The fracture tests were carried out on a commercial isostatic polycrystalline graphite. Thanks to the SEM analysis, the mean grain size was obtained while the density was determined through the buoyancy method that permits the measuring of the bulk volume of a sample by submerging it in a bath of mercury and observing the increase in weight of the bath, following the Archimede principle.

The material properties of the tested graphite are listed in Table 1: mean grain size is $2 \mu \mathrm{m}$, porosity $7 \%$, bulk density of $1850 \mathrm{~kg} / \mathrm{m}^{3}$, mean tensile strength of $28.5 \mathrm{MPa}$, the Young modulus of $8050 \mathrm{MPa}$ and shear modulus of $3.35 \mathrm{GPa}$.

$\mathrm{T}$ a

Mechanical Properties of Isostatic Graphite

\begin{tabular}{||l|c|}
\hline \multicolumn{1}{|c|}{ Material property } & Value \\
\hline Elastic modulus $E, \mathrm{MPa}$ & 8050 \\
\hline Shear modulus $G, \mathrm{MPa}$ & 3354 \\
\hline Poisson's ratio $v$ & 0.2 \\
\hline Ultimate torsion strength $\tau_{t}, \mathrm{MPa}$ & 30 \\
\hline Ultimate compression strength $\sigma_{c}, \mathrm{MPa}$ & 110 \\
\hline Ultimate tensile strength $\sigma_{t}, \mathrm{MPa}$ & 46 \\
\hline Fracture toughness $K_{\mathrm{I} c}, \mathrm{MPa} \sqrt{\mathrm{m}}$ & 1.06 \\
\hline Density $\left[\mathrm{kg} / \mathrm{m}^{3}\right]$ & 1850 \\
\hline Porosity $[\%]$ & 7 \\
\hline Resistivity $[\mu \Omega]$ & 11 \\
\hline Thermal conductivity $[\mathrm{W} /(\mathrm{m} \cdot \mathrm{K})]$ & 110 \\
\hline
\end{tabular}

Since the graphite sometimes shows nonlinearity in the mechanical behavior, the definition of a single value as elastic modulus could be questionable. However, it must be underlined that Losty and Orchard [18] proved that the heat treatment of ungraphitized carbons reduced the Young modulus and the strength, while maintaining a constant strain energy at failure. These points were also highlighted by Greenstreet [19, 20].

Berto et al. [31-34], in their experimental work, used a single value for elastic modulus obtained through a load-displacement graphs. The deviation of the tested specimens from linear behavior at failure was less than $0.02 \%$. For the sake of completeness the Young modulus was measured referring to a load value with a deviation from linear behavior less than $0.01 \%$.

All the load-controlled tests were performed on a servo-hydraulic MTS bi-axial testing instrument $\left( \pm 100 \mathrm{kN} / \pm 110 \mathrm{~N} \cdot \mathrm{m}, \pm 75 \mathrm{~mm} / \pm 55^{\circ}\right)$. The device is provided with an MTS load-cell with an error of $\pm 0.5 \%$ at full scale. A MTS strain gauge axial extensometer (MTS 632.85F-14), with a gauge length equal to $25 \mathrm{~mm}$ was used for measuring the tensile elastic properties on plain specimens while a multi-axis extensometer MTS 632.80F-04 (with a gauge length equal to $25 \mathrm{~mm}$ ) was used for measuring the torsion elastic properties.

The tensile strength $\left(\sigma_{t}\right)$ was determined by means of axis-symmetric specimens with a net diameter of $12.5 \mathrm{~mm}$ on the net section and a diameter of $20 \mathrm{~mm}$ on the gross section, with a large root radius that assured a stress concentration factor less than 1.05.

The shear modulus $(G)$ and the torsion strength $\left(\tau_{t}\right)$ of the tested graphite were obtained thanks to the torque-angle graphs registered by the test instrument and the bi-axis extensometer. The ultimate shear strength $\tau_{t}$ was found to be equal to $30 \mathrm{MPa}$. 
2. Failure under Mixed Mode Loading. As stated in the introduction, a large number of papers is available in literature regarding studies on mode I and mixed mode fracture in cracked graphite specimens, while a very few papers are available related to brittle fracture of notched component, especially of U- or V-notched graphite components. Ayatollahi and Torabi [28] recently conducted a series of fracture tests considering only mode I loading on three different V-notched specimens made of a polycrystalline graphite material. They proposed a mean stress criterion to the estimation of their experimental results, with a very good accuracy.

Since the industrial relevance of notched components made in graphite under mixed mode loading (as shown in the introduction) and the literature lack, the first part of the experimental programme carried out by Berto et al. [31-34] was dedicated to the investigation of mixed mode brittle fracture in polycrystalline graphite from experimental and theoretical viewpoint $[33,34]$. First, with the aim to determine the fracture loads under different combinations of mode I and II load, different fracture experiments are conducted on centrally notched specimens, more specific U-notches and key-holes were considered. Figure 1 shows different inclined U-notches and a detail of an example of U-notched specimen characterized by a notch inclination angle equal to $60^{\circ}$ and tip radius $\rho=2 \mathrm{~mm}$. Figure 2 instead depicts some specimens weakened by central key-holes. For the estimation of the fracture load, the SED criterion is employed and the results are compared to the experimentally obtained fracture loads. The values of the properties employed in the SED approach are: the ultimate tensile strength, which was equal to $46 \mathrm{MPa}$, and the fracture toughness which was $1.06 \mathrm{MPa} \sqrt{\mathrm{m}}$ (see Table 1).

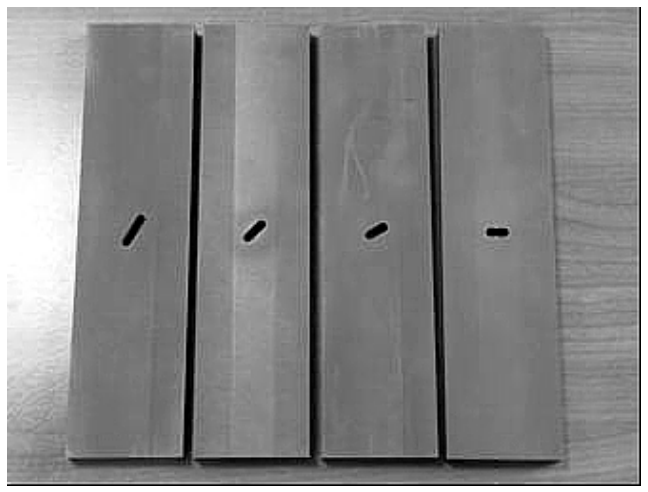

a

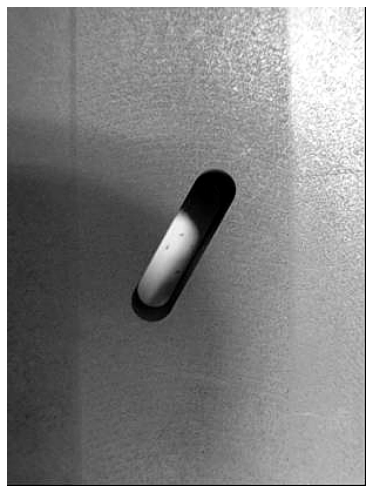

b

Fig. 1. Views of different inclined U-notches $\rho=2 \mathrm{~mm}$ (a); a detail of the notch with $\rho=2 \mathrm{~mm}$, $\beta=60^{\circ}$ (b).

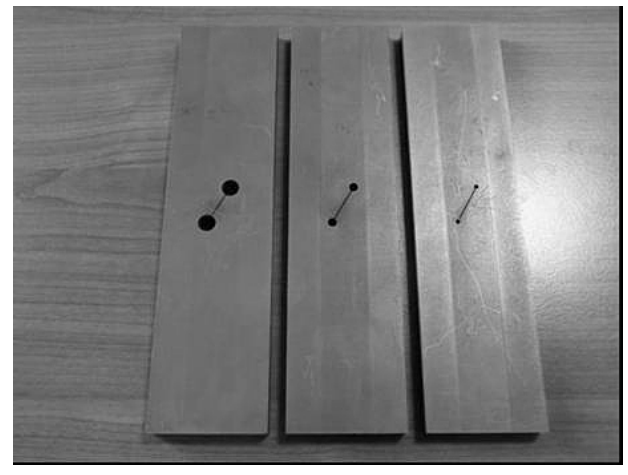

a

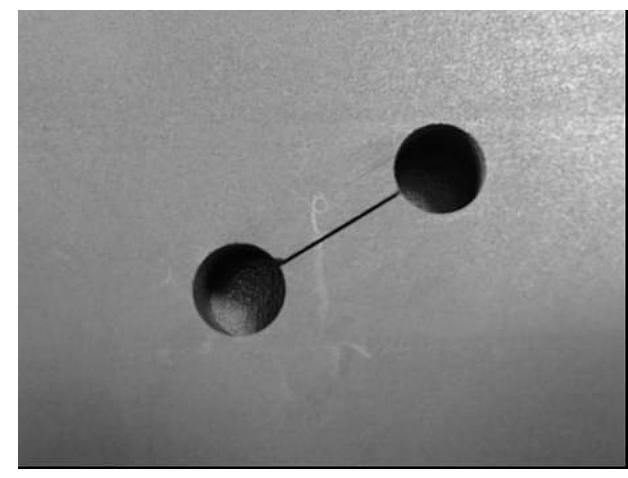

b

Fig. 2. Views of different inclined key-holes (a); a detail of the notch with $\rho=2 \mathrm{~mm}, \beta=30^{\circ}$ (b). 
The obtained SED critical value of the isostatic graphite considered in the present work is $W_{c}=0.13 \mathrm{MJ} / \mathrm{m}^{3}$, whereas the radius of the control volume [Eq. (1)], considering realistic plain strain conditions, is found to be equal to $0.17 \mathrm{~mm}$,

$$
R_{0}=\frac{(1+v)(5-8 v)}{4 \pi}\left(\frac{K_{\mathrm{I} c}}{\sigma_{t}}\right)^{2}
$$

An example of the experimental results and the theoretical SED based prediction is reported in Fig. 3. The $x$-axis reports the notch root radius for a particular value of the tilt angle, $\beta$. In detail, Fig. 3a depicts results of U-notch $\left(\beta=45^{\circ}\right)$, while Fig. 3b shows the case of a key-hole with an inclination of the notch equal to $60^{\circ}$. The figures show clearly a very good agreement between theoretical and experimental values.

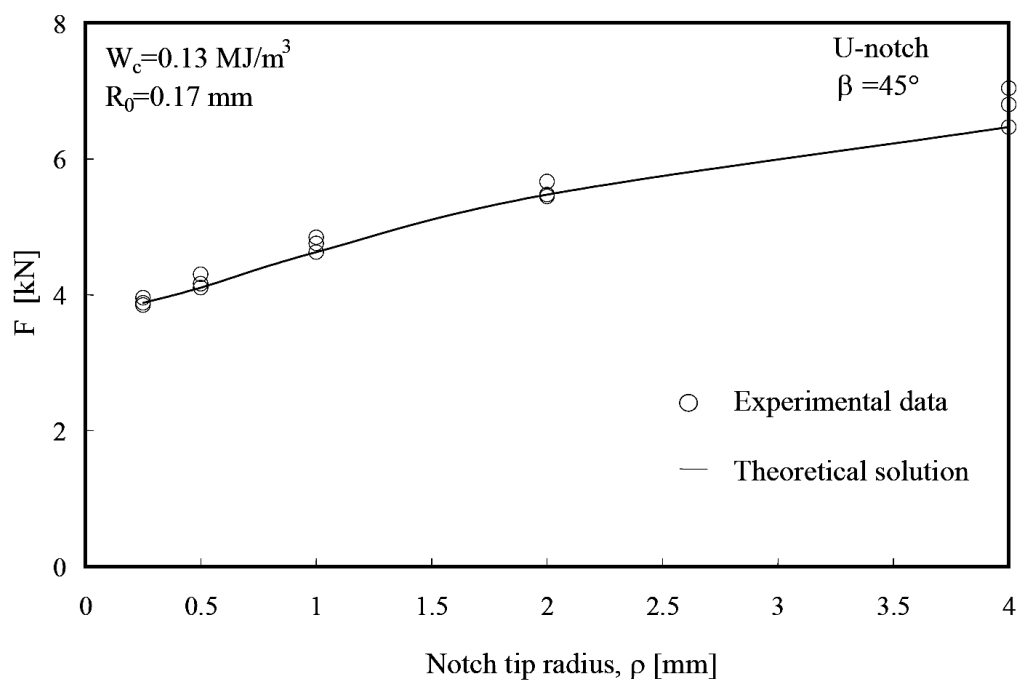

a

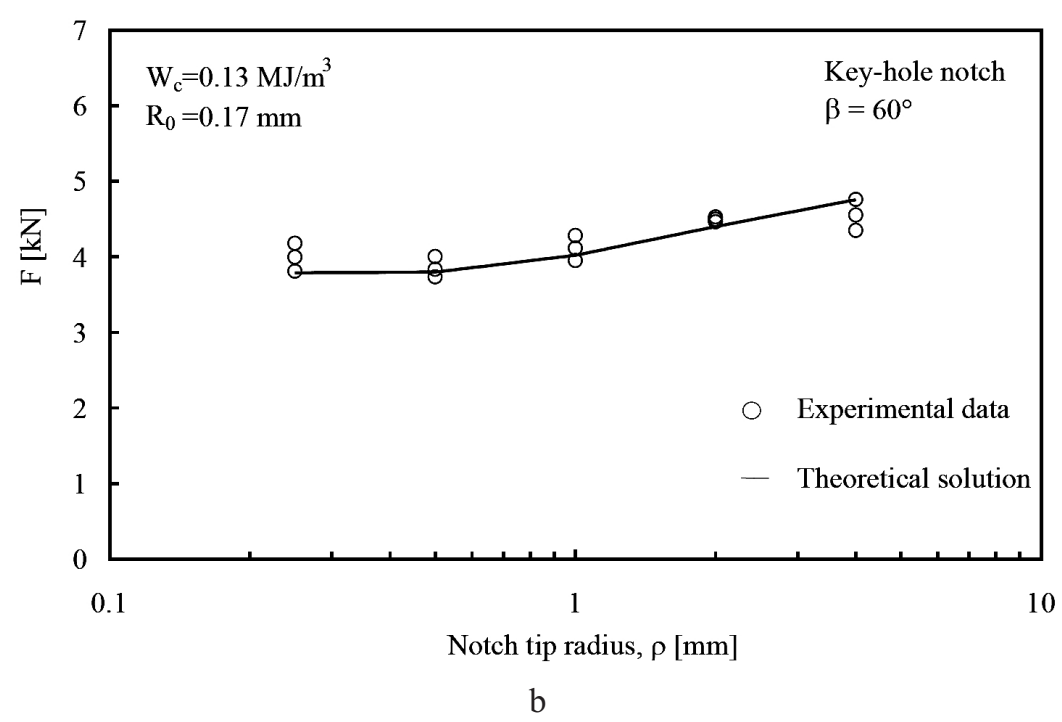

Fig. 3. Comparison between experimental and predicted values of the critical load for different notch radii and tilt angle of the U-notch $\beta=45^{\circ}$ (a) and key-hole $\beta=60^{\circ}$ (b). 
In Fig. 4, the square root of the SED normalized by the critical energy of the material is plotted as a function of the notch tip radius. It is clear that the plotted parameter is proportional to the fracture load. Moreover, data from key-holes and U-notches are contained in a very narrow scatterband that shows how the SED allows a unified synthesis, regardless of the notch shape and sharpness.

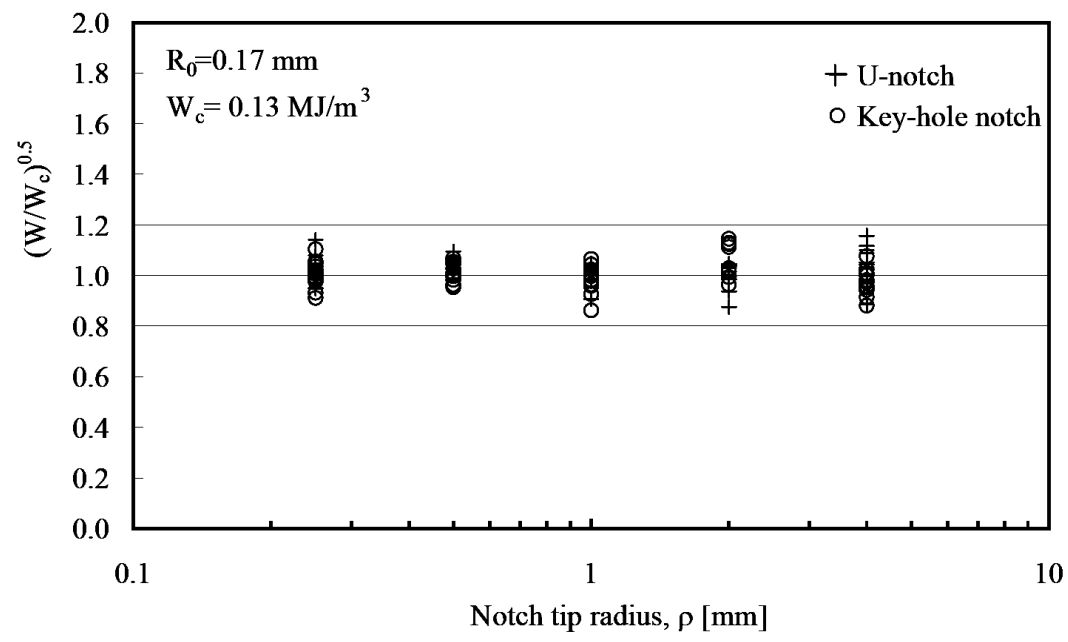

Fig. 4. Scatterband in terms of SED summarising the tested U-notched and key-hole notched specimens.

3. Torsion Loading. At the best of author knowledge, the current literature lacks completely any information concerning brittle failure of graphite components under mode III loading (such as bars under torsion). It is possible to find instead very few papers dealing with tension/torsion (mixed mode $\mathrm{I}+\mathrm{III}$ ) regarding ceramics like $\mathrm{Al}_{2} \mathrm{O}_{3}$ and inorganic glass [61-63].

Berto et al. [31] provided more than 70 new experimental results from static fracture of notched graphite specimens subjected to torsion loads varying notch root radii, notch opening angles and notch depths. These geometries are reported in Fig. 5, while the results are summarized in Fig. 6 and also in terms of SED approach in Fig. 7, once defined the critical radius of the graphite under torsion. Assuming the following values of the mechanical properties $\tau_{t}=30 \mathrm{MPa}$ and $G=3354 \mathrm{MPa}$, the critical SED for the tested graphite is $W_{c}=0.134 \mathrm{MJ} / \mathrm{m}^{3}$ (Table 1). In order to define the control volume (in other words the radius $R_{0}$ ), the values of the mode III fracture toughness $K_{\mathrm{III} c}$ and Poisson's ratio $v$ are necessary [see Eq. (2)]. Since these parameters are not available for specific data from cracked components, the parameter $K_{\text {IIIc }}$ has been estimated considering the results from two geometries with the minimum available radius, $\rho=0.1 \mathrm{~mm}$, and $2 \alpha=30^{\circ}$. Obviously, this procedure needs to be verified a posteriori by comparing the value of the estimated control radius and the real notch tip radius used in substitution of $\rho=0$ : if the results with the assumption of the radius $R_{0}$ are much greater than the notch tip radius $\rho$, the procedure can be accepted.

$$
R_{0}=\left(\sqrt{\frac{e_{3}}{1+v}} \frac{K_{\mathrm{III} c}}{\tau_{t}}\right)^{1 /\left(1-\lambda_{3}\right)} .
$$

Through Eq. (2), assuming $\tau_{t}=30 \mathrm{MPa}, e_{3}=0.379, v=0.2$, and $\left(1-\lambda_{3}\right)=0.5455$, $R_{0}$ results to be $1.0 \mathrm{~mm}$, that is ten times greater than the minimum notch tip radius, $\rho=$ $0.1 \mathrm{~mm}$. 


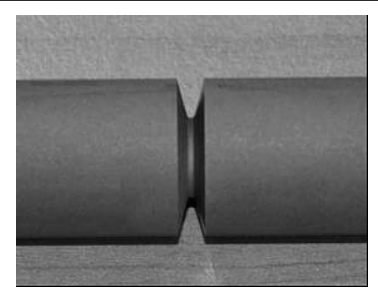

V-notch, $2 \alpha=30^{\circ}$

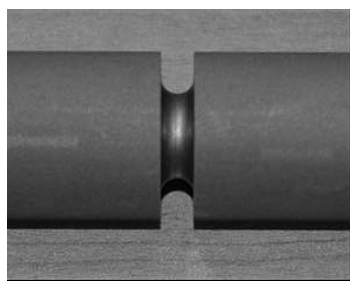

U-notch

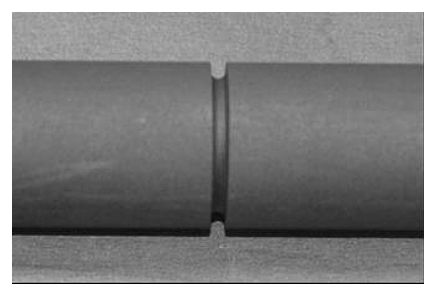

U-notch

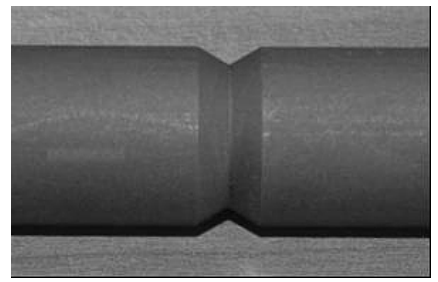

V-notch, $2 \alpha=120^{\circ}$

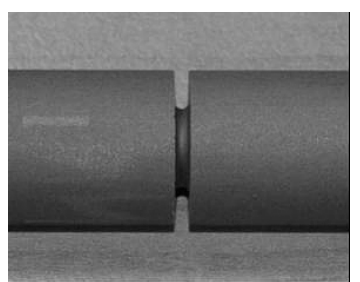

U-notch

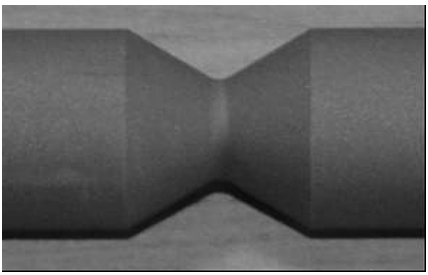

V-notch, $2 \alpha=120^{\circ}$

Fig. 5. Different notch shapes used in the test specimens under torsion.

Figure 6 reports the most significant results as a function of the notch radius $\rho$ for semicircular notches. In details, the experimental values of the critical loads (depicted with open dots) have been compared with the theoretical predictions based on the constancy of SED in the control volume (depicted with solid line). The good agreement with the experimental results is clear. This holds true also for the other specimens, although the relevant plots have been omitted here for the sake of brevity.

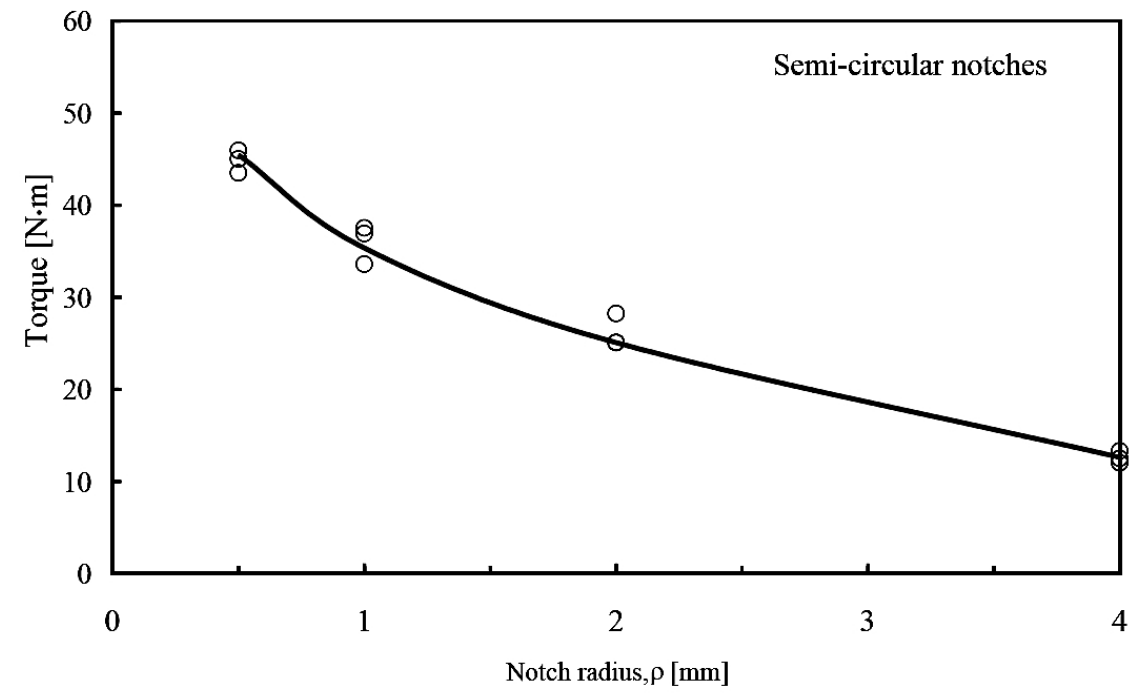

Fig. 6. Comparison between theoretical and experimental results.

Figure 7 depicts the synthesis in terms of the square root value of the averaged energy (with control radius equal to $R_{0}$ ) normalized with the critical energy of the material and as a function of the notch tip-critical radius ratio.

Indeed, the ratio on the vertical axis is proportional to the fracture load. From the figure, it is clear that the scatter of the data is very limited and almost independent of the notch opening angle. In fact, 68 out of 70 experimental values fall inside a scatterband 


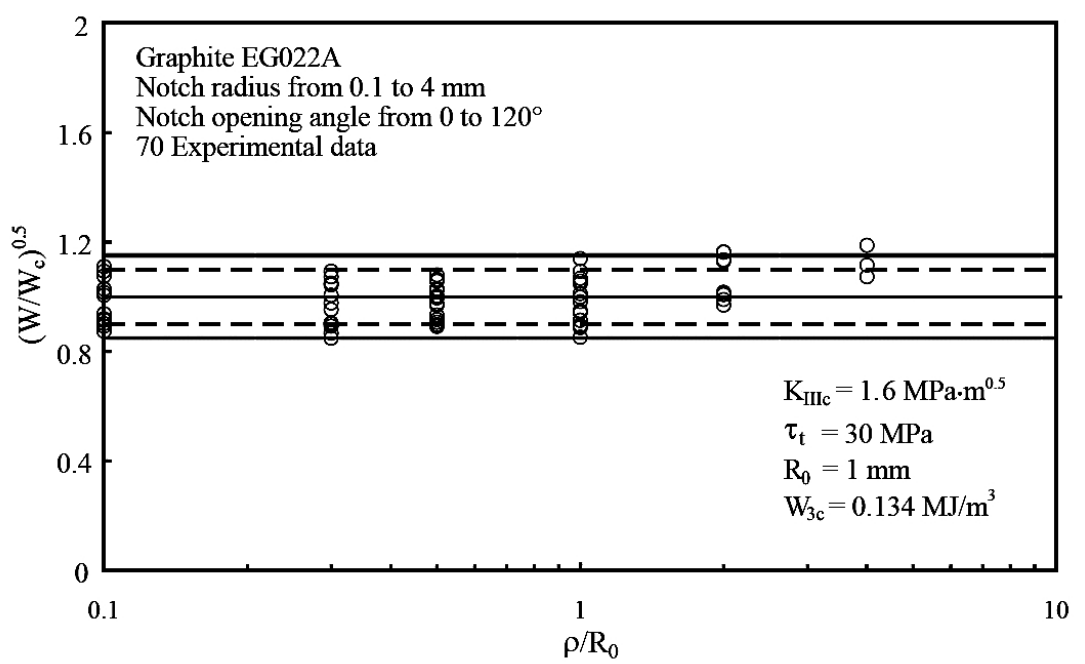

Fig. 7. Synthesis based on SED of the results from torsion tests.

ranging from 0.85 to 1.15 , and many of the results (about 75 percent) are inside a scatterband of the range $0.9-1.1$, which was the typical scatter range for notched graphite components tested under in-plane mixed tension-shear loading. These considerations underline the very good accuracy of the SED approach.

4. Compression Loading. Dealing with the strength under compression loading conditions, only a contribution by Kawakami [30] is relevant for the present paper. In that work, data from notched graphite specimens were summarized. Other contributions dealing with static failures [30, 64-71] consider instead other materials. For the sake of completeness, a brief review of the main contributions is reported below.

Cotterell [64] faced the apparent paradox of two theories of fracture depending on whether the applied load is tensile or compressive. He considered a previous experimental work conducted by Hoek and Beniawski [65], in which the so called open slits, i.e., glass plates with elliptical holes of different inclination angles, were tested. Thanks to ultrasonic machining, the slits were provided with an average notch tip radius of 0.005 inches $(0.125 \mathrm{~mm})$. In order to study the variation of the initiation phase as a function of the inclination angle of the slit, the latter was increased gradually, relatively to the direction of the applied far-field stress. It was observed that the initiation occurred away from the root of the ellipse. Instead, when the orientation of the slit was less than 48 degrees with respect to the load direction, the initiation occurred at the root of the ellipse. The main conclusion by Cotterell, also re-analysing the data taken from [66], was that the initiation of fracture occurs when the crack extension force reaches a critical value and that in compression this force is always dependent on the root radius of the slit. This is true in both cases, although apparently fractures in compression and tension from open slits are explained by different theories.

Bell [66] was the first to document the idea of a dominant inclined failure plane in uniaxial compression test of plain specimens. Lajtai [67], instead, deeply investigated the fracture mechanism as the material proceeds through several stage of microfracture, starting from the intact state and finishing with the state of residual strength under compression. In conclusion of the impressive work conducted by Lajtai, it was underlined that brittle failure in compression is a very complex phenomena, that can be schematized in six stages in which the fracture develops:

1. Lateral yield and initiation of load-parallel tensile fractures.

2. Axial yield and initiation of load-normal shear fractures. 
3. Initiation of inclined shear fractures.

4. Strength failure.

5. Post-failure phenomena.

6. Faulting.

The first two processes evolve from elastic flaw. Stages 3, 4, and 6 may be interpreted in terms of a modified Coulomb model. Stage 5 occurs under conditions so complex as to defy rational analysis.

An attempt to provide an empirical fracture criterion under compression loading, was made by Lajtai et al. [68], based on experimental data from rocks and combined with an averaged state of stress in front of the crack tip to formulate a crack driver function.

The mechanisms of crack initiation and propagation related to models and criteria under compression loading were reviewed by Wang and Shrive [69]. In their work it is clear the complexity of brittle fracture in compression. Due to this complexity it is not surprising that a large variety of models and fracture criteria have been developed. Moreover, it is stated that mode I cracking remains a fundamental mechanism also under compression loading. At least, the crack propagation requires however a progressive loss of interatomic bonding and creation of new surface.

Another interesting topic regards the fracture propagation from circular cavities loaded in compression. Dzik and Lajtai [70] shown that the fracture may form in three basic positions around the cavity: at the tensile stress concentration (primary fracture), inside the material remote from the perimeter of the cavity, and at the compressive stress concentration. They observed that the propagation of primary fractures nucleated at the tensile stress concentration was size dependent. The crack growth was found to be different for small and large cavities: very stable crack growth was documented for the former, whereas an almost unstable crack growth was detected for the latter. Cavities of intermediate size displayed transitional behavior while in very small cavities there were no primary fractures and only remote failure occurred.

A review of the uniaxial compression test on brittle solid is presented in [71] considering mainly uncracked materials. The discussion focused on the description of the post-peak behavior, where strength softening and fractures propagating mainly in the axial direction of cylindrical specimens were observed. The main conclusion was that the post-peak axial stress was found to be a function of the axial displacement normalized by the radius of the specimen, but not of its height.

At the best of authors' knowledge, only one contribution deals with components weakened by V-notches made of graphite and subjected to compression [30]. Kawakami [30] conducted uniaxial tensile tests, compressive tests and thermal shock (by water quenching) on notched specimens made of IG-11 (fine grained isotropic graphite), Stackpole 2020 (SP2020, fine grained isotropic graphite) and PGX (molded anisotropic graphite). The water quenching were conducted in this way: the specimens were heated in $\mathrm{N}_{2}$ gas atmosphere and rapidly cooled by water quenching. This operation induced strong thermal stresses. In the tensile and compressive tests, the results from notch specimens were compared to the results of the smooth ones, in order to understand the notch effect. For the compressive tests, two notch geometries were considered: notches transverse to the load direction and parallel to the load direction. In these specimen configurations, a secondary tensile stress was always present locally at the notch tip, even if the external applied load was purely compressive. In this way, the only compressive component of the stress field was the stress parallel to the direction of the applied external load. In fact, due to Poisson's contraction effect, a tensile stress field was generated near the notch tip. For these reasons, those tests can be only partially considered as compressive, and the occurred fracture was mainly due to the tensile stress, generated as a secondary effect. An important consideration was reported in Kawakami's paper [30] quoting previous works by Greenstreet [19, 20] who tested graphite for nuclear applications: according to the Bach criterion [62], the failure was 
caused under compression by the transverse ultimate tensile strain. The main open point remains the identification of the critical parameter under compression.

Other historical criteria based on strain energy density, starting from the pioneering work by Beltrami [72], are due to Schleicher [73] and Stassi D'Alia [74, 75]. At the best of authors' knowledge, the first researcher that modified the total strain energy density criterion (Beltrami hypothesis) was Schleicher, in order to take into account the different strength properties exhibited by many materials under pure tension and pure compression uniaxial tests. In the same time, Stassi D'Alia proposed a criterion based on the definition of an energy parameter. This parameter was defined as the sum of the deviatoric work and of an energy parameter which depends on the mean stress and takes into account the parameter $\chi_{L}$, i.e., the ratio between the limit stresses for the material under tension $\left(\sigma_{L}\right)$ and compression $\left(\sigma_{L}^{\prime}\right)$, respectively.

All the studies mentioned above have considered the fracture phenomena in notched graphite components under either in-plane (mixed mode I+II) loading conditions or torsion loading. Instead, regarding brittle failure of graphite under a remote applied compression load, the current literature shows an evident lack of any information. Especially when all the stress components in the highly stressed region ahead of the notch tip are negative. A work carried out by Berto et al. [31] tried to fill partially this lack.

With the aim to give more experimental data regarding static fracture of notched graphite specimens subjected to pure compression, 40 new tests have been carried out with varying notch root radii and notch opening angles.

In order to explore the influence of the notch shape, different prismatic specimens were used for compression tests (Fig. 8). In details:

(i) three different notch opening angles, $2 \alpha=30,120$, and $135^{\circ}$, were taken into account;

(ii) the specimens with $2 \alpha=30^{\circ}$ were characterized by four different notch root radii, $\rho=0.5,1,2$, and $4 \mathrm{~mm}$;

(iii) for larger values of the opening angle, $2 \alpha=120$ and $135^{\circ}$, five notch root radii were considered, $\rho=0.25,0.5,1,2$, and $4 \mathrm{~mm}$;

(iv) the notch depth varied as a function of the notch radius, keeping constant the distance between the centers of the round notches $(30 \mathrm{~mm})$;

(v) the thickness of the specimens was constant and equal to $10 \mathrm{~mm}$;

(vi) the width of the upper and lower gripper zones was constant and equal to $50 \mathrm{~mm}$.
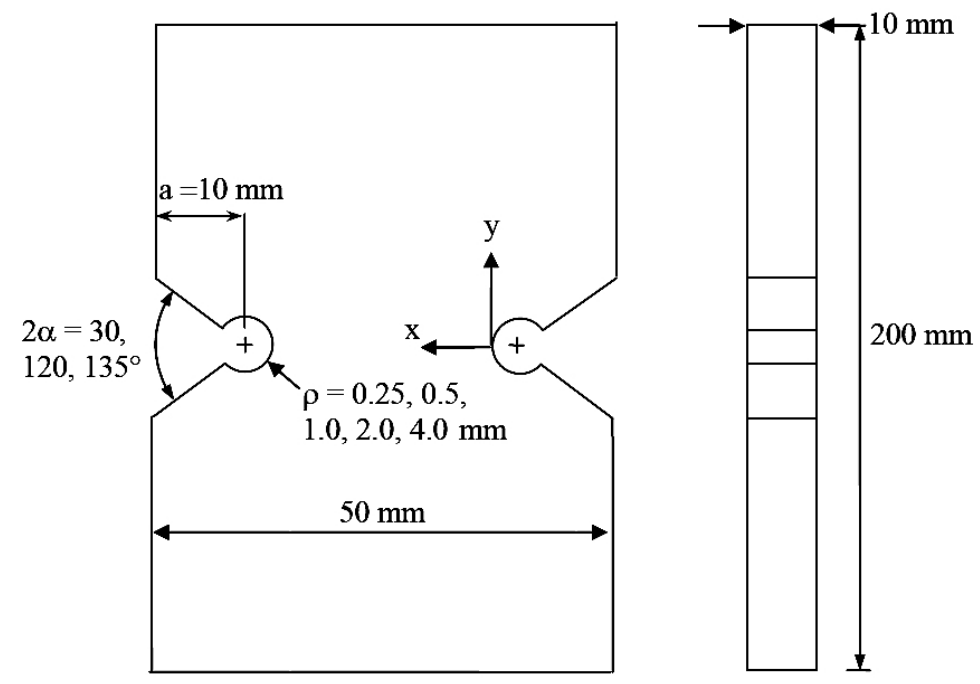

Fig. 8. Geometry of the specimens weakened by V-notches with end holes. 
The fracture initiation and propagation was continually monitored during the tests by using an optical microscope and a dedicate software called LAS (Leica Application Suite). It was observed that, regardless of the notch geometries (opening angle and radius), the initiation occurred always at the notch tip. Regarding the propagation phase instead, the generated crack starts to propagate along the notch bisector line and tends to deviate from its direction further away from the notch tip. Finally, the crack path turns quickly towards the direction of the applied compressive load.

The image of a presumed crack in the initiation phase is shown in Fig. 9 for the case of an opening angle $2 \alpha=135^{\circ}$ and a notch radius $\rho=4 \mathrm{~mm}$. It is easily visible in Fig. $9 \mathrm{a}$ that the crack initiates at the notch tip, propagates along the notch bisector line and then deviates from that line at a distance lower than $\rho / 2$ from the notch tip. A material detachment near the free surfaces of the specimen, in the neighborhood of the tip, is generated by this deviation (Fig. 9b).

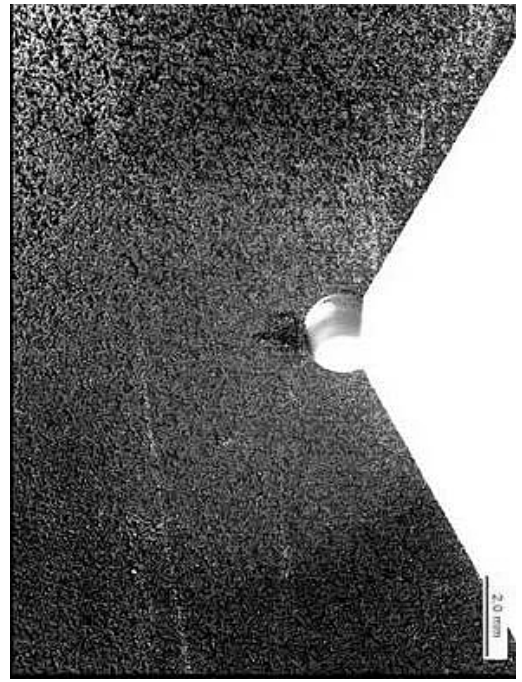

a

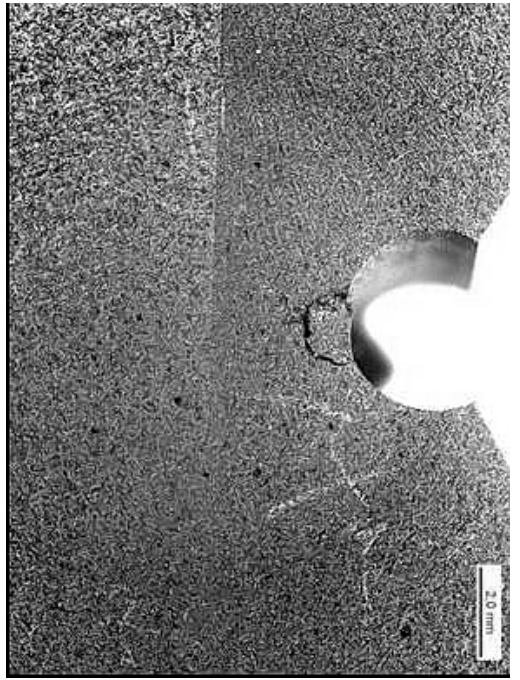

b

Fig. 9. Damage initiation and propagation for $2 \alpha=135^{\circ}$ and $\rho=4 \mathrm{~mm}$. Notch profile (a) and zoom of the notch tip (b).

During the tests, a thermographic analysis has been also carried out through an infrared camera AGEMA THV $900 \mathrm{LW} / \mathrm{ST}$, that is able to detect infrared radiation in the range of wave lengths between 8 and $12 \mu \mathrm{m}$ with a resolution of $0.1^{\circ} \mathrm{C}$. Figure 10 shows a sequence of images recorded by the employed infrared camera during the compressive tests, under displacement control at $0.2 \mathrm{~mm} / \mathrm{min}$. The considered specimen is characterized by a notch opening angle $2 \alpha=135^{\circ}$ and a notch radius $\rho=4 \mathrm{~mm}$. The increase in temperature measured during the test was found to be quite limited $\left(2^{\circ} \mathrm{C}\right)$. It was observed the progressive damage in the zone along the bisector line, while the material debris are laterally thrown out from the specimen until the final failure. In the last stage of the fracture process, the fragmentation of the net section of the specimen became evident. These observations allow to confirm that the crack propagates along the notch bisector line at least for the largest values of the notch radius.

In case of compression loading, Eq. (1) cannot be used to evaluate the critical radius because of the difficulty, under compressive load, to define the fracture toughness and critical ultimate strength. Therefore, in these conditions, an empirical approach can be a good solution for determining $R_{0}$ for a graphite notched component under compression. 

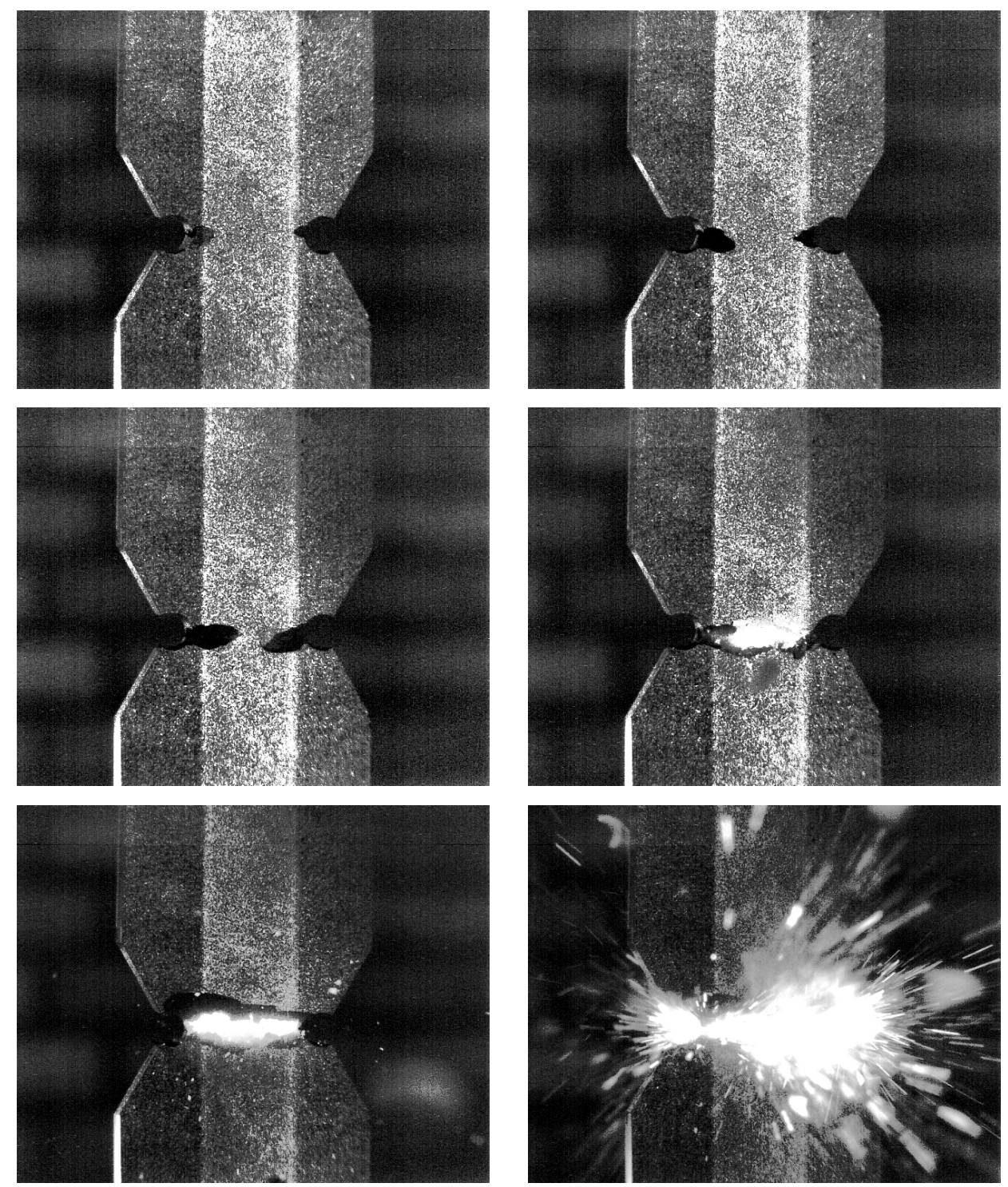

Fig. 10. Sequence of images recorded by means of an infrared camera during a compressive load applied under displacement control at $0.2 \mathrm{~mm} / \mathrm{min}$ under pure compression. The specimen is characterized by a notch radius $\rho=4 \mathrm{~mm}$ and a notch opening angle $2 \alpha=135^{\circ}$.

The shape of the volume is shown in Fig. 11a while the contour line of the SED are depicted in Fig. $11 \mathrm{~b}$ and $11 \mathrm{c}$ for the cases $2 \alpha=30^{\circ}$ and $\rho=4 \mathrm{~mm}$ and $2 \alpha=30^{\circ}$ and $\rho=0.5 \mathrm{~mm}$, respectively.

Value of $R_{0}$ was empirically determined through the data related to the two specimens with $2 \alpha=30^{\circ}$ and $\rho=0.5$ and $4 \mathrm{~mm}$. Figure 12 plots the SED as a function of $R_{0}$ and shown that, for different control radius, from 0.5 to $1.5 \mathrm{~mm}$, the two curves referred to $\rho=0.5$ and $4 \mathrm{~mm}$ have an intersection at $R_{0}=1 \mathrm{~mm}$. In other words, the two geometries, at the critical load, are characterized by the same value of the SED which is independent of the acuity and shape of the notch.

The determined value $R_{0}=1 \mathrm{~mm}$, which corresponds to a critical value of the SED equal to $1.40 \mathrm{MJ} / \mathrm{m}^{3}$, has been used for the fracture assessment of the critical loads. 


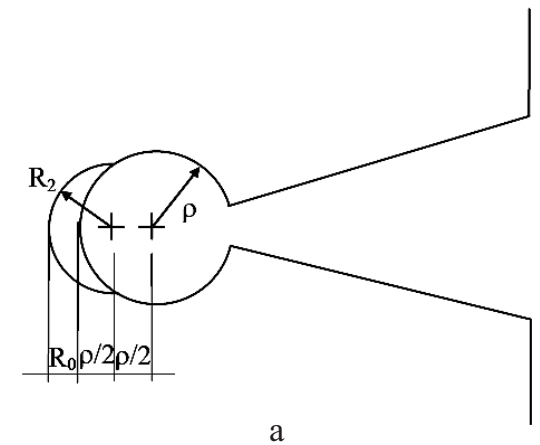

a
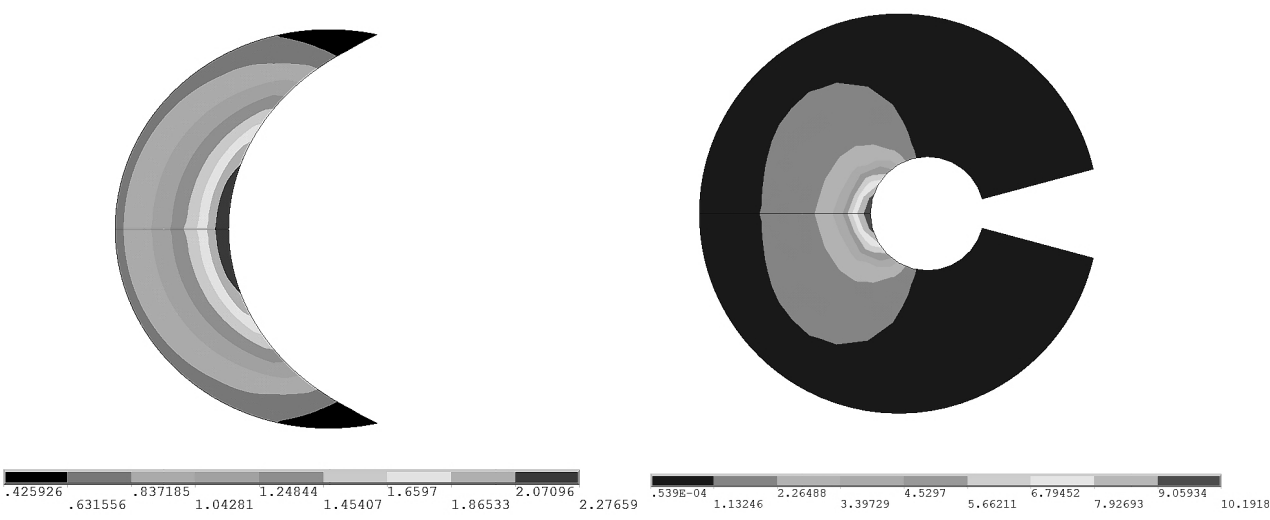

$4 \mathrm{~b}$

$\mathrm{c}$

Fig. 11. Shape of the control volume (a), case $2 \alpha=30^{\circ}, \rho=4 \mathrm{~mm}, R_{0}=1 \mathrm{~mm}$ (b), case $2 \alpha=30^{\circ}$, $\rho=0.5 \mathrm{~mm}, R_{0}=1 \mathrm{~mm}(\mathrm{c})$.

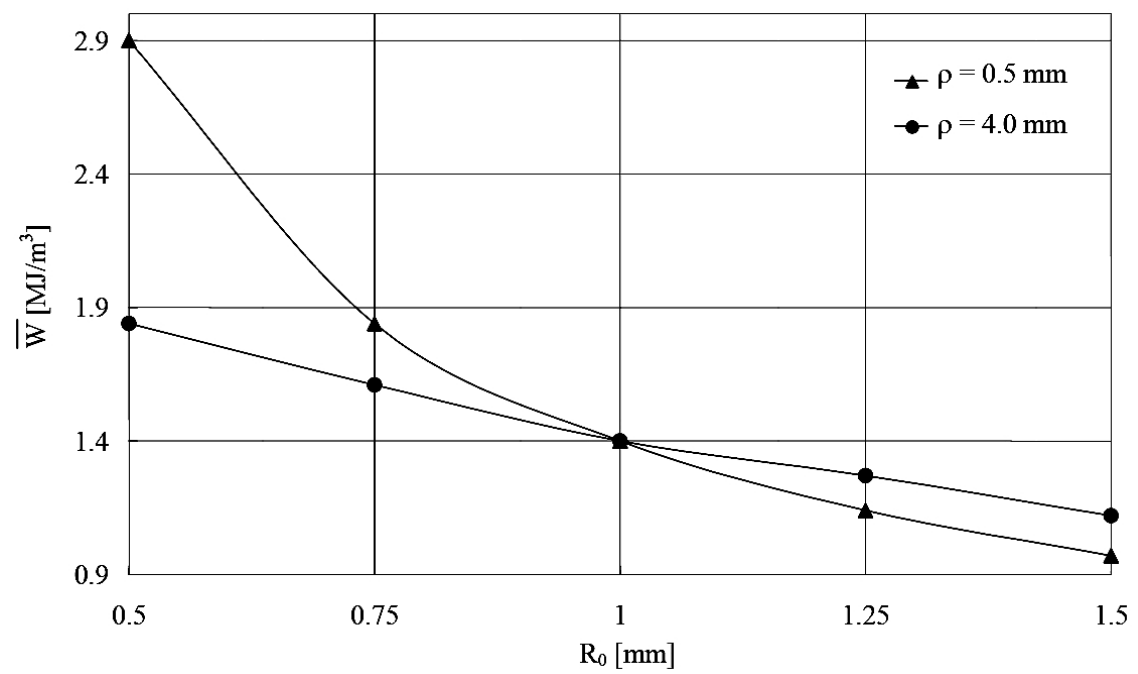

Fig. 12. Determination of the control volume $\left(2 \alpha=30^{\circ}\right)$.

The critical SED for the material under compression was found to be equal to 1.40 $\mathrm{MJ} / \mathrm{m}^{3}$, while it is equal to $0.131 \mathrm{MJ} / \mathrm{m}^{3}$ under tension [76] and $0.134 \mathrm{MJ} / \mathrm{m}^{3}$ under torsion [31], considering the same material. The value of the radius $R_{0}$ is $1.0 \mathrm{~mm}$ under torsion [31] but decrease to $0.17 \mathrm{~mm}$ in pure mode I and in-plane mixed mode. 
By making the square root of the ratio between the critical SED under compression and the critical SED under tension, that is equal to 11.1 , the ratio between the critical stresses under compression and tension is obtained. From this simple formula, the calculated critical stress higher than of the tested polycrystalline graphite under compression is about 3.3 times its ultimate tension strength. This is in good agreement with some previous results reported in the literature [21, 30]. In particular, Kawakami gave a ratio equal to 3.15 [30]. In a more recent contribution, Nemeth and Bratton [21], regardless of the graphite type, gave an indicative and approximate ratio equal to 4.0. The good agreement with the cited works supports the approach adopted here for determining the value of control radius for graphite under compression loadings.

Figure 13 gives the results based on the SED approach in a graphical form. The experimental values of the critical loads (open dots) have been compared with the theoretical predictions based on the constancy of SED in the control volume (solid line). The plots are given as a function of the notch radius $\rho$ considering separately the data from V-notches with $2 \alpha=30^{\circ}$ (Fig. 13a), $2 \alpha=120^{\circ}$ (Fig. 13b) and $2 \alpha=135^{\circ}$ (Fig. 13c). The theoretically predicted loads and experimental results are in a very good agreement.

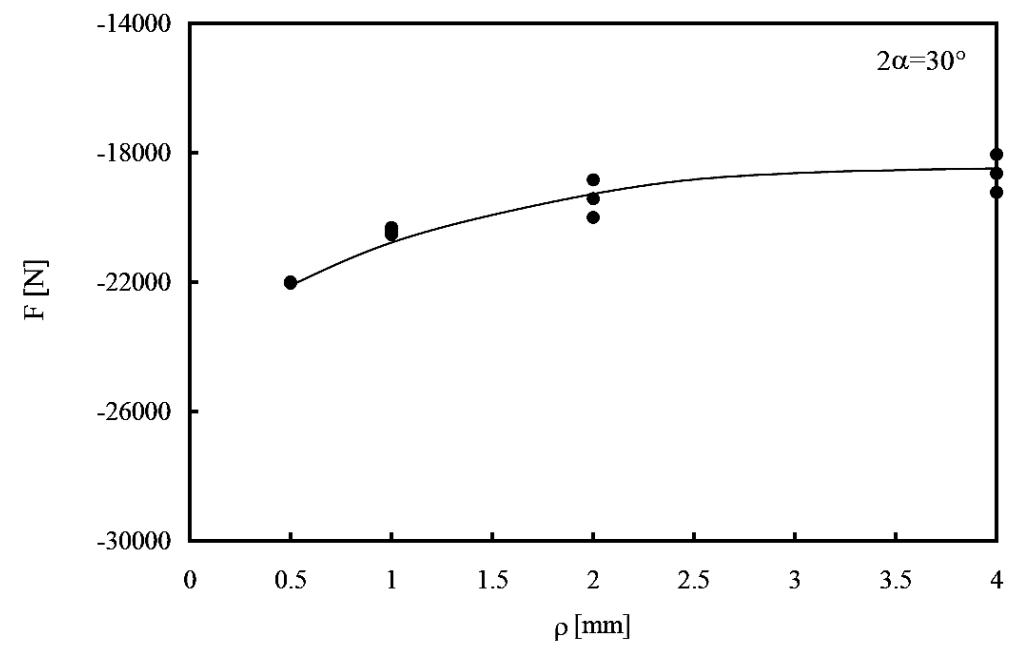

a

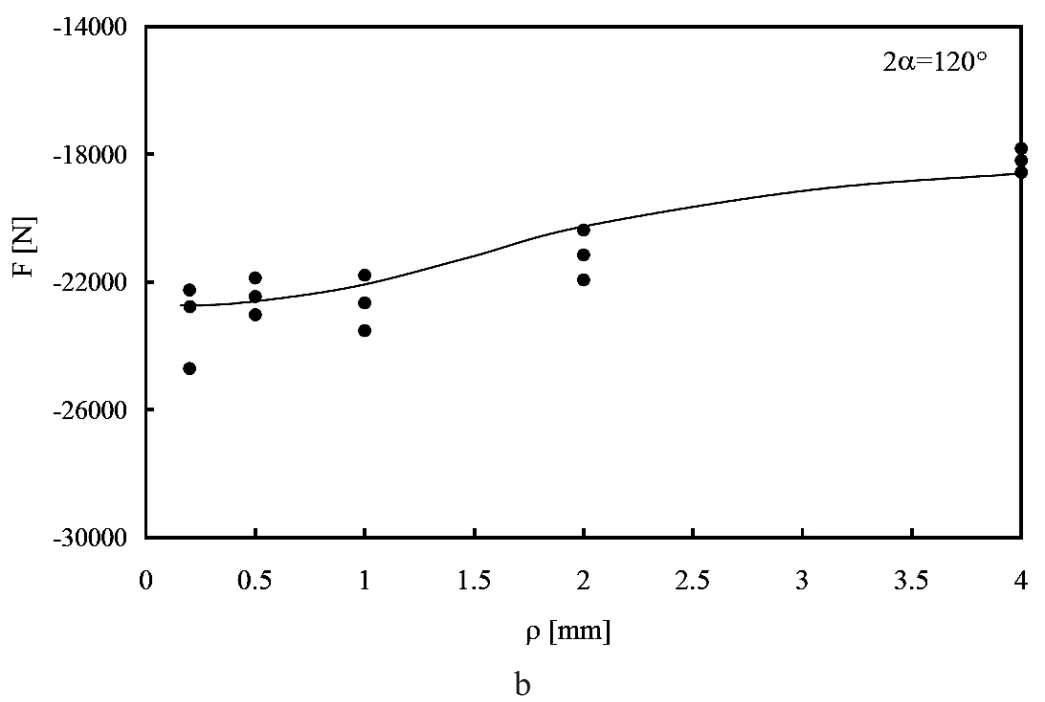




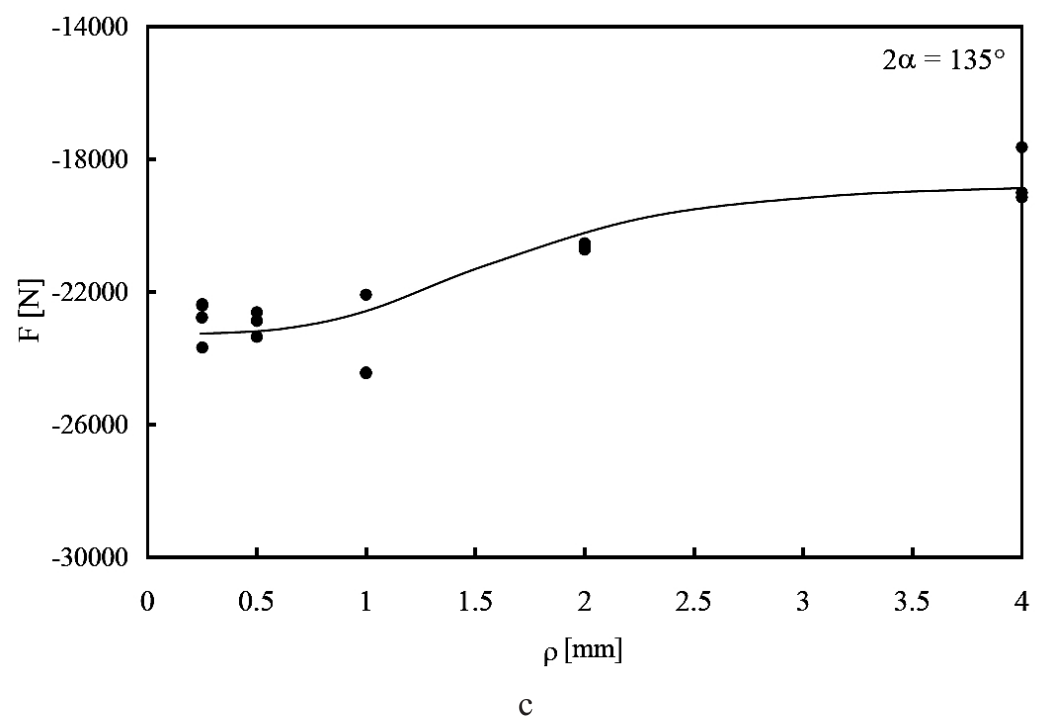

Fig. 13. Fracture assessment based on SED for the considered notch opening angles $30^{\circ}$ (a), $120^{\circ}$ (b), and $135^{\circ}$ (c).

Figure 14 shows the square root value of the SED averaged on the control volume of radius $R_{0}$, normalised with respect to the constant value of the critical SED $\left(1.40 \mathrm{MJ} / \mathrm{m}^{3}\right)$ as a function of the notch radius $\rho$. The ratio on the vertical axis is proportional to the fracture load. From the figure, it is clear that the scatter of the data is very limited and almost independent of the notch opening angle. In fact, all the experimental values obtained for graphite fall inside a scatterband ranging from 0.9 to 1.1 . One should also note that the majority of the results are inside a scatter ranging from 0.95 to 1.05 . These considerations underline the very good accuracy of the SED approach for fatigue assessment of notched components made of graphite, under compression loadings.

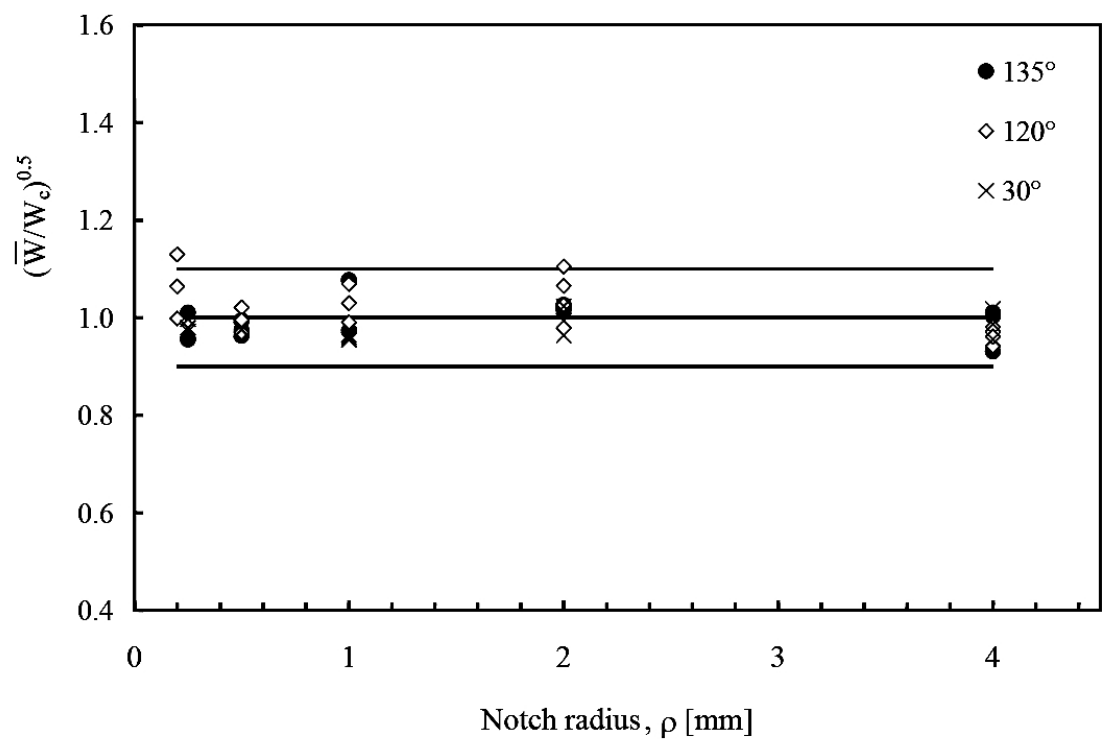

Fig. 14. Scatterband based on SED as a function of the notch radius. 
5. Final Synthesis from All Graphite Specimens. Figure 15 shows a final synthesis in terms of the square root value of the local energy averaged over the control volume, normalized with respect to the critical energy of the material as a function of the notch tip radius. The data presented by Berto et al. [31-34] (dealing with the same graphite tested under mixed mode I+II) contains all torsion and compression loading, and so all the data belongs to the same scatterband. The plotted parameter is proportional to the fracture load.

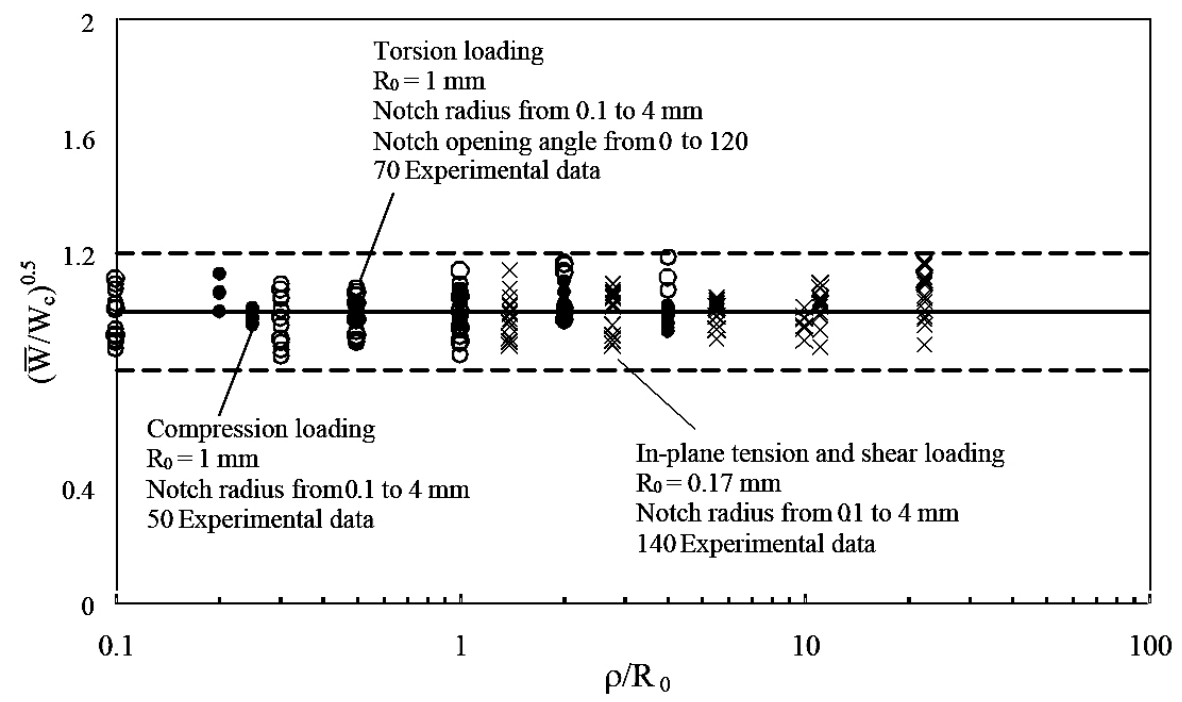

Fig. 15. Scatterband based on SED as a function of the notch radius of all the data.

Altogether more than 300 experimental data are summarized in a narrow scatterband within 0.8 and 1.2 proving the applicability of the SED criterion under different loading conditions, once the critical radius has been determined.

Conclusions. The brittle fracture on V-notched isostatic graphite specimens has been investigated experimentally, theoretically and numerically under mixed mode (I+II), torsion and compression loading. Different combinations of the notch tip radius, the notch opening angle and the tilt angle of the notch have been considered.

The averaged value of the strain energy density over a control volume has been used in combination with the equivalent local mode I concept to assess the static strength of the specimens subjected to different loading modes. The center of the control volume is located on the notch edge, where the principal stress reaches its maximum value. The correct orientation is obtained by a rigid rotation of the crescent-shaped volume while the size depends on the fracture toughness and the ultimate strength of the material. This methodology has been already used in the literature to analyse U- and V-shaped notches subjected to mode I loading with very good results and advantages with respect to classic approaches. The results obtained in this new work show, also under mixed mode loading condition, good agreement between experimental data and theoretical predictions.

It is shown that, since the good agreement between the experimental loads to failure and the values estimated by means of SED approach, the method based on the local SED is suitable for the graphite stressed under different loading conditions. More than 300 experimental data are summarized in a narrow scatterband ranging from 0.8 to 1.2. The applicability of the SED criterion under different loading conditions, once the critical radius has been determined, is clearly demonstrated.

Since the good agreement between the theoretical and experimental results, it can be asserted that for the isostatic graphite, the critical energy and the radius of the control 
volume are material properties, which depend on the grain size. Moreover, under different loadings modes, the synthesis supports the choice of a crescent shape volume which seems to be suitable to characterize the material behavior.

\section{Резюме}

Наведено огляд експериментальних и розрахункових даних, отриманих точним розв'язком і числовими методами, найновіших досліджень крихкого руйнування ізостатичного полікристалічного графіту. Дослідження проводили на зразках із V-подібним надрізом при навантаженні по змішаній моді (I+II) крутінням і стиском для різних комбінацій таких параметрів, як радіус скруглення, кут розхилу і нахилу V-подібного надрізу. Статичну міцність досліджуваних зразків оцінювали в рамках підходу, що базується на осередненій по контрольному об'єму густині енергії деформації. Центр контрольного об'єму знаходиться у вершині надрізу, де має місце максимальне значення головного напруження. Точна орієнтація контрольного об'єму оцінюється шляхом жорсткого обертання хрестоподібної ділянки, в той час як його розміри залежать від в'язкості руйнування і границі міцності матеріалу. Дану методологію достатньо успішно використовували в літературних джерелах для аналізу U- та V-подібних надрізів при навантаженні по моді I, при цьому отримано хороші результати і деякі переваги порівняно з класичним підходом. Показано хорошу збіжність експериментальних і розрахункових результатів для випадку навантаження по змішаній моді.

1. H. Awaji and S. Sato, "Combined mode fracture toughness measurement by the disk test,” J. Eng. Mater. Technol., 100, 175-182 (1978).

2. Y. Yamauchi, M. Nakano, K. Kishida, and T. Okabe, "Impact measurement of mixed-mode fracture toughness for brittle materials using edge-notched half-disk specimen," J. Soc. Mater. Sci. Japan., 50, 229-234 (2001).

3. Y. Yamauchi, M. Nakano, K. Kishida, and T. Okabe, "Measurement of fracture toughness for brittle materials under mixed-mode impact loading using center-notched disk specimen,” J. Soc. Mater. Sci. Jpn., 49, 1324-1329 (2000).

4. M. Li, M. Tsujimura, and M. Sakai, "Crack-face grain interlocking/bridging of a polycrystalline graphite: The role in mixed mode fracture," Carbon, 37, 1633-1639 (1999).

5. L. Shi, H. Li, Z. Zou, et al., "Analysis of crack propagation in nuclear graphite using three-point bending of sandwiched specimens," J. Nucl. Mater., 372, 141-151 (2008).

6. J.-A. J. Wang and K. C. Liu, "An innovative technique for evaluating fracture toughness of graphite materials," J. Nucl. Mater., 381, 177-184 (2008).

7. T. Etter, J. Kuebler, T. Frey, et al., "Strength and fracture toughness of interpenetrating graphite/aluminium composites produced by the indirect squeeze casting process," Mater. Sci. Eng. A, 386, 61-67 (2004).

8. Y.-J. Yum and H. You, "Pure mode I, II and mixed mode interlaminar fracture of graphite/epoxy composite materials," J. Reinf. Plast. Compos., 20, 794-808 (2001).

9. S. N. Wosu, D. Hui, and P. K. Dutta, "Dynamic mixed-mode I/II delamination fracture and energy release rate of unidirectional graphite/epoxy composites," Eng. Fract. Mech., 72, 1531-1558 (2005).

10. R. A. Jurf and R. B. Pipes, "Interlaminar fracture of composite materials," J. Compos. Mater., 16, 386-395 (1982).

11. B. A. Latella and T. Liu, "The initiation and propagation of thermal shock cracks in graphite," Carbon, 44, 3043-3048 (2006). 
12. S. Sato, K. Kawamata, H. Awaji, et al., "Thermal shock resistance and fracture toughness during the graphitization process," Carbon, 19, 111-118 (1981).

13. S. Sato, H. Awaji, and H. Akuzawa, "Fracture toughness of reactor graphite at high temperature," Carbon, 16, 95-102 (1978).

14. R. H. Knibbs, "Fracture in polycrystalline graphite," J. Nucl. Mater., 24, 174-187 (1967).

15. B. Allard, D. Rouby, G. Fantozzi, et al., "Fracture behaviour of carbon materials," Carbon, 29, 457-468 (1991).

16. T. D. Burchell, "A microstructurally based fracture model for polygranular graphites," Carbon, 34, 297-316 (1996).

17. E. V. Lomakin, A. I. Zobnin, and A. V. Berezin, "Finding the fracture toughness characteristics of graphite materials in plane strain," Strength Mater., 7, No. 4, 484-487 (1975).

18. H. H. W. Losty and J. S. Orchard, "The strength of graphite," in: Proc. of the Fifth Conference on Carbon, Pennsylvania State University, MacMillan, New York (1962), 1, pp. 537-546.

19. W. L. Greenstreet, Mechanical Properties of Artificial Graphites - A Survey Report, Oak Ridge, TN (1968).

20. W. L. Greenstreet, J. E. Smith, and G. T. Yahr, "Mechanical properties of EGCR-type AGOT graphite," Carbon, 7, 15-45 (1969).

21. N. N. Nemeth and R. L. Bratton, Statistical Models of Fracture Relevant to NuclearGrade Graphite: Review and Recommendations, NASA/TM-2011-215805, Cleveland, Ohio (2011).

22. M. Mostafavi and T. J. Marrow, "In situ observation of crack nuclei in poly-granular graphite under ring-on-ring equi-biaxial and flexural loading," Eng. Fract. Mech., 78, 1756-1770 (2011).

23. M. Mostafavi and T. J. Marrow, "Quantitative in situ study of short crack propagation in polygranular graphite by digital image correlation," Fatigue Fract. Eng. Mater. Struct., 35, 695-707 (2012).

24. M. Mostafavi, M. J. J. Schmidt, B. J. Marsden, and T. J. Marrow, "Fracture behaviour of an anisotropic polygranular graphite (PGA)," Mater. Sci. Eng. A, 558, 265-277 (2012).

25. M. Mostafavi, S. A. McDonald, P. M. Mummery, and T. J. Marrow, "Observation and quantification of three-dimensional crack propagation in poly-granular graphite," Eng. Fract. Mech., 110, 410-420 (2013).

26. M. Mostafavi, S. A. McDonald, H. Çetinel, et al., "Flexural strength and defect behaviour of polygranular graphite under different states of stress," Carbon, 59, 325-336 (2013).

27. M. R. Ayatollahi, F. Berto, and P. Lazzarin, "Mixed mode brittle fracture of sharp and blunt V-notches in polycrystalline graphite," Carbon, 49, 2465-2474 (2011).

28. M. R. Ayatollahi and A. R. Torabi, "Tensile fracture in notched polycrystalline graphite specimens," Carbon, 48, 2255-2265 (2010).

29. D. K. Bazaj and E. E. Cox, "Stress-concentration factors and notch-sensitivity of graphite," Carbon, 7, 689-697 (1969).

30. H. Kawakami, "Notch sensitivity of graphite materials for VHTR," J. Atom. Energ. Soc. Jpn., 27, 357-364 (1985). 
31. F. Berto, P. Lazzarin, and M. R. Ayatollahi, "Brittle fracture of sharp and blunt V-notches in isostatic graphite under torsion loading," Carbon, 50, 1942-1952 (2012).

32. F. Berto, P. Lazzarin, and M. R. Ayatollahi, "Brittle fracture of sharp and blunt V-notches in isostatic graphite under pure compression loading," Carbon, 63, 101116 (2013).

33. P. Lazzarin, F. Berto, and M. R. Ayatollahi, "Brittle failure of inclined key-hole notches in isostatic graphite under in-plane mixed mode loading," Fatigue Fract. Eng. Mater. Struct., 36, 942-955 (2013).

34. F. Berto, P. Lazzarin, and C. Marangon, "Brittle fracture of U-notched graphite plates under mixed mode loading," Mater. Des., 41, 421-432 (2012).

35. G. C. Sih, "Strain-energy-density factor applied to mixed mode crack problems," Int. J. Fract., 10, 305-321 (1974).

36. R. Brighenti and A. Carpinteri, "Buckling and fracture behaviour of cracked thin plates under shear loading," Mater. Des., 32, 1347-1355 (2011).

37. A. Carpinteri, C. Ronchei, and S. Vantadori, "Stress intensity factors and fatigue growth of surface cracks in notched shells and round bars: two decades of research work," Fatigue Fract. Eng. Mater. Struct., 36, 1164-1177 (2013).

38. R. Brighenti and A. Carpinteri, "Surface cracks in fatigued structural components: a review," Fatigue Fract. Eng. Mater. Struct., 36, 1209-1222 (2013).

39. R. Brighenti, A. Carpinteri, and A. Spagnoli, "Influence of material microvoids and heterogeneities on fatigue crack propagation," Acta Mech., 225, 3123-3135 (2014).

40. R. Brighenti and A. Carpinteri, "Some considerations on failure of solids and liquids," Strength Mater., 42, No. 2, 154-166 (2010).

41. R. Brighenti, A. Carpinteri, and S. Vantadori, "Fatigue life assessment under a complex multiaxial load history: an approach based on damage mechanics," Fatigue Fract. Eng. Mater. Struct., 35, 141-153 (2012).

42. R. Brighenti and A. Carpinteri, "A notch multiaxial-fatigue approach based on damage mechanics," Int. J. Fatigue, 39, 122-133 (2012).

43. S. Vantadori, A. Carpinteri, and D. Scorza, "Simplified analysis of fracture behaviour of a Francis hydraulic turbine runner blade," Fatigue Fract. Eng. Mater. Struct., 36, 679-688 (2013).

44. P. Lazzarin and R. Zambardi, "A finite-volume-energy based approach to predict the static and fatigue behavior of components with sharp V-shaped notches," Int. J. Fract., 112, 275-298 (2001).

45. P. Lazzarin and F. Berto, "Some expressions for the strain energy in a finite volume surrounding the root of blunt V-notches," Int. J. Fract., 135, 161-185 (2005).

46. F. Berto and P. Lazzarin, "Recent developments in brittle and quasi-brittle failure assessment of engineering materials by means of local approaches," Mater. Sci. Eng. R Rep., 75, 1-48 (2014).

47. F. Berto, A. Campagnolo, M. Elices, and P. Lazzarin, "A synthesis of polymethylmethacrylate data from U-notched specimens and V-notches with end holes by means of local energy," Mater. Des., 49, 826-833 (2013).

48. P. Lazzarin, A. Campagnolo, and F. Berto, "A comparison among some recent energy- and stress-based criteria for the fracture assessment of sharp V-notched components under mode I loading," Theor. Appl. Fract. Mech., 71, 21-30 (2014). 
49. A. R. Torabi, A. Campagnolo, and F. Berto, "Mode II brittle fracture assessment of key-hole notches by means of the local energy," J. Test. Eval., 44, No. 3. Paper in press, DOI: 10.1520/JTE20140295.

50. D. Radaj, F. Berto, and P. Lazzarin, "Local fatigue strength parameters for welded joints based on strain energy density with inclusion of small-size notches," Eng. Fract. Mech., 76, 1109-1130 (2009).

51. P. Lazzarin, P. Livieri, F. Berto, and M. Zappalorto, "Local strain energy density and fatigue strength of welded joints under uniaxial and multiaxial loading," Eng. Fract. Mech., 75, 1875-1889 (2008).

52. F. Berto, P. Lazzarin, and P. Gallo, "High-temperature fatigue strength of a coppercobalt-beryllium alloy," J. Strain Anal. Eng. Des., 49, 244-256 (2013).

53. F. Berto, P. Gallo, P. Lazzarin, "High temperature fatigue tests of un-notched and notched specimens made of 40CrMoV13.9 steel," Mater. Des., 63, 609-619 (2014).

54. F. Berto, P. Lazzarin, and C. Marangon, "Fatigue strength of notched specimens made of 40CrMoV13.9 under multiaxial loading," Mater. Des., 54, 57-66 (2014).

55. F. Berto, A. Campagnolo, and P. Lazzarin, "Fatigue strength of severely notched specimens made of Ti-6Al-4V under multiaxial loading," Fatigue Fract. Eng. Mater. Struct., 38, 503-517 (2015).

56. P. Lazzarin, F. Berto, and M. Zappalorto, "Rapid calculations of notch stress intensity factors based on averaged strain energy density from coarse meshes: theoretical bases and applications," Int. J. Fatigue, 32, 1559-1567 (2010).

57. L. P. Pook, F. Berto, A. Campagnolo, and P. Lazzarin, "Coupled fracture mode of a cracked disc under anti-plane loading," Eng. Fract. Mech., 128, 22-36 (2014).

58. A. Campagnolo, F. Berto, and P. Lazzarin, "The effects of different boundary conditions on three-dimensional cracked discs under anti-plane loading", Eur. J. Mech. - A/Solids, 50, 77-86 (2015).

59. F. J. Gómez, M. Elices, F. Berto, and P. Lazzarin, "Local strain energy to assess the static failure of U-notches in plates under mixed mode loading," Int. J. Fract., 145, 29-45 (2007).

60. F. Berto, P. Lazzarin, F. J. Gómez, and M. Elices, "Fracture assessment of U-notches under mixed mode loading: two procedures based on the 'equivalent local mode I' concept," Int. J. Fract., 148, 415-433 (2007).

61. K. R. Raju, "Effect of depth of side grooves in double torsion specimens on plane strain fracture toughness," Int. J. Fract., 17, R189-R190 (1981).

62. X. Zheng, K. Zhao, H. Wang, and J. Yan, "Failure criterion with given survivability for ceramic notched elements under combined tension/torsion," Mater. Sci. Eng. A, 357, 196-202 (2003).

63. X. L. Zheng, K. Zhao, and J. H. Yan, "Fracture and strength of notched elements of brittle material under torsion," Mater. Sci. Technol., 21, 539-545 (2005).

64. B. Cotterell, "Brittle fracture in compression," Int. J. Fract. Mech., 8, 195-208 (1972).

65. E. Hoek and Z. T. Bieniawski, "Brittle fracture propagation in rock under compression," Int. J. Fract. Mech., 1, 137-155 (1965).

66. J. F. Bell, The Experimental Foundations of Solid Mechanics, in: S. Flügge (Ed.), Encyclopedia of Physics, Vol. VIa/1, Springer-Verlag, Berlin-Heidelberg-New York (1973). 
67. E. Z. Lajtai, "Brittle fracture in compression," Int. J. Fract., 10, 525-536 (1974).

68. E. Z. Lajtai, B. J. Carter, and M. L. Ayari, "Criteria for brittle fracture in compression," Eng. Fract. Mech., 37, 59-74 (1990).

69. E. Z. Wang and N. G. Shrive, "Brittle fracture in compression: Mechanisms, models and criteria," Eng. Fract. Mech., 52, 1107-1126 (1995).

70. E. J. Dzik and E. Z. Lajtai, "Primary fracture propagation from circular cavities loaded in compression," Int. J. Fract., 79, 49-64 (1996).

71. I. Vardoulakis, J. F. Labuz, E. Papamichos, and J. Tronvoll, "Continuum fracture mechanics of uniaxial compression on brittle materials," Int. J. Solids Struct., 35, 4313-4335 (1998).

72. E. Beltrami, "Sulle condizioni di resistenza dei corpi elastici," Il Nuovo Cimento, 18, 145-155 (in Italian) (1885).

73. F. Schleicher, "Der Spannungszustand an der Fliessgrenze (Plastizitätsbedingung)," $Z$. Angew. Math. Mech., 6, 199-216 (1926).

74. F. Stassi-D'Alia, Un Paraboloide di Rivoluzione Quale Condizione di Plasticita, L'ingegnere (1951).

75. F. Stassi-D'Alia, Teoria della Plasticita e sue Applicazioni, Palermo (1958).

76. F. Berto, P. Lazzarin, and D. Radaj, "Fictitious notch rounding concept applied to sharp V-notches: evaluation of the microstructural support factor for different failure hypotheses. Part I: Basic stress equations," Eng. Fract. Mech., 75, 3060-3072 (2008).

Received 17. 12. 2014 